\title{
Vitamin C may affect lung infections
}

\author{
Harri Hemilä Pekka Louhiala
}

J R Soc Med 2007; 100:495-498

Vitamin C was identified in the early 1900s in the search for a deficient substance responsible for scurvy, which was a serious disease of sailors in the Age of Sail. ${ }^{1,2}$ In the early literature, scurvy was directly linked to pneumonia. The American paediatrician Alfred Hess carried out extensive studies on scurvy and summarized autopsy findings as follows: 'pneumonia, lobular or lobar, is one of the most frequent complications [of scurvy] and causes of death' and 'secondary pneumonias, usually broncho-pneumonic in type, are of common occurrence, and in many [scurvy] epidemics constitute the prevailing cause of death'. ${ }^{3}$ Starting in the 1930s, some German and US physicians proposed that vitamin C would be beneficial in the treatment of pneumonia. ${ }^{4}$

Although the burden of pneumonia has decreased dramatically in developed countries during the past century, lung infections are still a leading cause of mortality and morbidity globally. ${ }^{5}$ Therefore, the question of whether vitamin $\mathrm{C}$ might affect pneumonia is an issue worthy of systematic consideration.

The best known physiological function of vitamin $\mathrm{C}$ is its participation in collagen hydroxylation, and the symptoms of scurvy are largely explained by changes in collagen metabolism. The biochemistry of vitamin $\mathrm{C}$ is, however, much more complex. For example, it also participates in the enzymatic synthesis of dopamine, carnitine and a number of neuroendocrine peptides. ${ }^{2,6,7}$

In the immune system, the major role of vitamin $\mathrm{C}$ seems to be as a physiological antioxidant, protecting host cells against oxidative stress caused by infections. Its concentration in phagocytes and lymphocytes is very high compared with the level in plasma, indicating that vitamin $\mathrm{C}$ may have functional roles in these immune system cells. In various experimental settings, vitamin $\mathrm{C}$ increased the functioning of phagocytes, the proliferation of T-lymphocytes and the production of interferon, and decreased the replication of viruses. ${ }^{2}$ According to animal studies, vitamin $\mathrm{C}$ increases resistance to various viral and bacterial infections. Moreover, many infections, including pneumonia, lead to reduced vitamin $\mathrm{C}$ levels in plasma, leukocytes and urine. ${ }^{2}$ Because of these changes in metabolism, vitamin $\mathrm{C}$

Department of Public Health, PO Box 41, University of Helsinki, FIN-00014, Finland

Correspondence to: Harri Hemilä

Email: harri.hemila@helsinki.fi might have a therapeutic effect on pneumonia patients. Thus there is a biological rationale to examine the effect of vitamin $\mathrm{C}$ on infections in humans.

We carried out a systematic review, published in the Cochrane Library, in which we examined the role of vitamin $\mathrm{C}$ supplementation on preventing and treating pneumonia. ${ }^{4}$ We identified three controlled trials reporting on the preventive effect and two on the therapeutic effect of vitamin $\mathrm{C}$ against pneumonia. ${ }^{8-12}$ Each of the trials found a statistically significant benefit of vitamin $\mathrm{C}$ supplementation on at least one clinically relevant outcome. In the therapeutic trials, vitamin $\mathrm{C}$ was tested over and above the normal medication, which included antibiotics. ${ }^{11,12}$ Two of the five trials were randomized, placebo-controlled double-blind trials. ${ }^{10,12}$ The other three trials were technically deficient to varying degrees, but their shortcomings do not cause biases that would give evident explanations to the reported differences in favour of the vitamin $\mathrm{C}$ groups. ${ }^{4}$

\section{IMPLICATIONS OF TRIAL FINDINGS}

Five controlled trials carried out in three different countries over four decades indicate that vitamin $\mathrm{C}$ may affect pneumonia in humans. All five trials test the general question of whether vitamin $\mathrm{C}$ intake level may affect pneumonia susceptibility under some conditions. However, the trials are clinically so heterogeneous that a pooled estimate is not meaningful for either preventive or therapeutic effect. Therefore, the positive findings cannot be generalized widely.

The three prevention trials examined schoolboys in the UK in the 1940s and military personnel (i.e. participants with substantially dissimilar living conditions compared with current ordinary Western adults). ${ }^{8-10}$ An important feature in these prevention trials is the particularly high incidence of pneumonia: in two studies it was 30 and 120 cases per 1000 person-years in the control arms, ${ }^{8,10}$ and in one study it was $10 \%$ of the control arm within a week after hospitalization because of influenza. ${ }^{9}$ In contrast, the incidence of pneumonia is about three cases per 1000 person-years in the middle-aged Western population. ${ }^{13}$ One therapeutic trial studied patients aged 66-94 in the UK and another was carried out in the former Soviet Union with adult male patients aged from 20 to over $60 .{ }^{11,12}$ 


\section{Marginal vitamin C deficiency}

An issue of particular importance in vitamin $\mathrm{C}$ trials is the dosage of the vitamin in the diet and in supplements. A difference between vitamin $\mathrm{C}$ and control arms may result from a very low dietary intake in the control arm, which may be labelled 'marginal vitamin $\mathrm{C}$ deficiency', or from high-dose supplementation in the vitamin $\mathrm{C}$ arm. In the former case, a small dosage of supplement would produce a similar effect, whereas in the latter case the large dose is essential. Previously, a low dietary intake level was proposed as an explanation for the reduction of common cold incidence by vitamin $\mathrm{C}$ supplementation in a set of four trials with UK males. ${ }^{14}$

Treating 'marginal deficiency' is a plausible explanation for the reduction in pneumonia incidence by vitamin $\mathrm{C}$ supplementation in the prophylactic trial by Glazebrook and Thomson with a group of boys in a UK boarding school during World War II. ${ }^{8}$ Dietary vitamin C intake among the study participants was very low $(10-15 \mathrm{mg} /$ day $)$, and the supplementation dose was also low $(0.05-0.3 \mathrm{~g} /$ day).

In their therapeutic trial with elderly hospitalized patients in the UK, Hunt et al. reported low plasma vitamin $\mathrm{C}$ levels (mean $23 \mu \mathrm{mol} / \mathrm{L}$ ) and the supplement dose was low $\left(0.2 \mathrm{~g} /\right.$ day). ${ }^{12}$ Furthermore, the benefit of vitamin $\mathrm{C}$ was restricted to the most ill patients, who had particularly low vitamin $\mathrm{C}$ levels. Thus the benefit of vitamin $\mathrm{C}$ supplementation may be explained as treatment of marginal deficiency. In this study, cases of acute bronchitis and pneumonia were combined together and thus the outcome was lung infections rather than pneumonia specifically. In young people, acute bronchitis usually has a viral aetiology, whereas the majority of pneumonia cases are caused by bacteria. However, the patients in the Hunt et al. trial were all over 60 years of age and their acute bronchitis was 'often acute exacerbation of chronic bronchitis', implying bacterial aetiology.

A recent cohort study found no association between vitamin $\mathrm{C}$ intake and pneumonia incidence in middle-aged men in the USA. ${ }^{13}$ There are, however, substantial differences between this observational study and the controlled trials. The cohort consisted of male health professionals, which means a population with great interest in factors that affect health, thus diverging from the three prophylactic trials. Furthermore, the median vitamin $\mathrm{C}$ intake of the lowest quintile was high $(95 \mathrm{mg} /$ day $)$, so that the cohort cannot test whether 'marginal vitamin $\mathrm{C}$ deficiency' might increase susceptibility to pneumonia. Finally, the incidence of pneumonia was only three cases per 1000 person-years, which is considerably lower than in the controlled trials. Thus, we consider that biological rather than methodological differences are the most appropriate explanations for the divergence in the findings of this cohort study and the three controlled trials.

\section{Heavy physical stress}

In the Pitt and Costrini trial, ${ }^{10}$ plasma vitamin $C$ level was initially high (mean $56 \mu \mathrm{mol} / \mathrm{L}$ ), corresponding to a dietary intake of $100 \mathrm{mg} /$ day or more, ${ }^{7}$ and the plasma concentration increased only slightly with the high supplement dose of $2 \mathrm{~g} /$ day. Thus, this trial is incompatible with treating marginal vitamin $\mathrm{C}$ deficiency. The participants of the Pitt and Costrini trial were US Marine recruits in the training camp, and thus were very fit men who exercised heavily and frequently.

There is other evidence indicating that antioxidants may affect respiratory infections in physically stressed people. Vitamin E, a lipid-soluble antioxidant which interacts with vitamin $\mathrm{C}$, reduced the incidence of pneumonia by half in male smokers who carried out leisure-time exercise ${ }^{15}$ and vitamin $\mathrm{C}$ halved the incidence of common cold in six trials with participants under heavy acute physical stress, four of them focusing on marathon runners. ${ }^{16}$ Thus, hard recruit training in the Pitt and Costrini trial is a plausible explanation for the reduction in pneumonia incidence by high-dose vitamin $\mathrm{C}$ supplementation.

\section{PHYSIOLOGICAL FUNCTIONS OF VITAMIN C}

Although it has been pointed out that the complex biochemistry of vitamin $\mathrm{C}$ may indicate effects on diseases other than scurvy, ${ }^{6,7}$ there is no consensus about the importance of the 'non-scorbutic' effects of vitamin C. It is usually assumed that the physiological role of vitamin $\mathrm{C}$ is simply to prevent scurvy. ${ }^{2}$

So far, the strongest evidence for the non-scorbutic effects of vitamin $\mathrm{C}$ is the large number of trials on the common cold. There is firm evidence that regular vitamin $\mathrm{C}$ supplementation reduces common cold duration in the general population; however, the effect is modest and the practical importance of this effect is not clear. ${ }^{16}$ Vitamin C also reduced the incidence of common cold in people under heavy acute physical stress, although it had no effect on the incidence in 'ordinary' people. ${ }^{16}$ The series of five controlled trials on pneumonia gives further evidence for the non-scorbutic effects of vitamin C.

However, even if we recognize that there are nonscorbutic effects of vitamin $\mathrm{C}$, it is possible that they are important only in specific conditions. For example, it is possible that variation in vitamin $\mathrm{C}$ intake does not affect the immune system in the ordinary Western population because of their relatively high dietary intake levels. Vitamin C might, however, be a limiting factor in populations with low dietary intakes. 
Heavy physical stress causes oxidative stress, and a recent study found that vitamin $\mathrm{C}$ administration prevented exercise-induced oxidative changes. ${ }^{17}$ This protection against oxidative stress provides a rationale for the findings of controlled trials and thus heavy physical stress may also be a condition under which vitamin $\mathrm{C}$ supplementation could be beneficial.

Furthermore, vitamin $\mathrm{C}$ metabolism is affected by various infections, ${ }^{2}$ which suggests that there might be treatment benefits. Although the controlled trials on the common cold and pneumonia indicate physiological effects for vitamin $\mathrm{C}$ in addition to preventing and treating scurvy, the practical importance of these effects is not established.

\section{SAFETY OF VITAMIN C}

Approximately $10 \mathrm{mg} /$ day of vitamin $\mathrm{C}$ prevents scurvy but the safe dose range extends to grams per day. In the US nutritional recommendations, the 'tolerable upper intake level' is stated to be $2 \mathrm{~g}$ /day for adults. The basis for this upper limit is the appearance of diarrhoea; ${ }^{18}$ however, this is a trivial adverse effect that disappears quickly when the intake level is reduced. Although there have been speculations of potential harms of large doses of vitamin $\mathrm{C}$, they have been shown to be unfounded. $2,7,18$ Furthermore, it has been stated that patients with pneumonia can take up to $100 \mathrm{~g}$ /day of vitamin C without developing diarrhoea, possibly because of the changes in vitamin $\mathrm{C}$ metabolism caused by the severe infection. ${ }^{19}$ Finally, in a recent pharmacokinetic study, participants were administered up to $100 \mathrm{~g}$ of vitamin $\mathrm{C}$ intravenously within a few hours without any reported adverse effects, indicating the safety of such a high dose in healthy people. ${ }^{20}$

\section{THE WAY FORWARD}

Overt vitamin C deficiency - scurvy — is rare and mostly a problem of poor and undernourished populations. Recently, outbreaks have been reported in refugee camps. ${ }^{21}$ Even though scurvy is very rare in Western countries, cases have also been reported among hospital patients. ${ }^{22}$ Marginally low vitamin $\mathrm{C}$ status is not uncommon, although epidemiological data are rather sparse. Furthermore, published surveys have used variable cut-off limits for low plasma vitamin $\mathrm{C}$ levels and study cohorts have been selected in different ways. ${ }^{23-29}$

With high dietary intakes $(>500 \mathrm{mg} /$ day $)$, the plasma vitamin C level will plateau at $70-80 \mu \mathrm{mol} / \mathrm{L} .{ }^{7}$ In comparison, clinical symptoms of scurvy may appear when the plasma level falls below $10 \mu \mathrm{mol} / \mathrm{L} .{ }^{7,21,30}$ Surveys have found that plasma vitamin $\mathrm{C}$ levels below $11 \mu \mathrm{mol} / \mathrm{L}$ are found in $14 \%$ of males and $10 \%$ of females from the USA, ${ }^{23}$ in $19 \%$ of males and $13 \%$ of females from India, ${ }^{24}$ in $14 \%$ of elderly people living at home and $40 \%$ of elderly people living in institutions in the UK, ${ }^{25}$ in $23 \%$ of children and $39 \%$ of women in Mexico, ${ }^{26}$ and in $79-93 \%$ of men from Western Russia. ${ }^{27}$ In a cohort of pregnant women from rural India, $45 \%$ had plasma vitamin C level below $4 \mu \mathrm{mol} / \mathrm{L}^{2}{ }^{28}$ In a cohort of pregnant or lactating women from Gambian villages in the rainy season, the average plasma vitamin $\mathrm{C}$ level fell to $10 \mu \mathrm{mol} / \mathrm{L} .^{29}$ Although vitamin C status varies with time, geography and population groups, these figures indicate that low vitamin $\mathrm{C}$ levels are not rare, even though frank scurvy is. Thus, if low vitamin $\mathrm{C}$ levels increase the risk of pneumonia, this effect may be of wide interest globally. The possible effect of vitamin $\mathrm{C}$ on the risk of respiratory infections in physically stressed people is also highly relevant.

Immediate practical conclusions cannot be drawn from the studies discussed in this essay. The findings suggesting benefit of vitamin $\mathrm{C}$ against lung infections in restricted population groups are important from the public health point of view and motivate further studies. Nevertheless, the effects of vitamin $\mathrm{C}$ on respiratory infections are also important at the level of fundamental concepts, because they indicate that the effects of vitamin $\mathrm{C}$ are not limited to preventing and treating scurvy.

Competing interests None.

Guarantor HH.

Contributorship $\mathrm{HH}$ wrote the first draft and both authors contributed to the revision of the text to its final form.

\section{REFERENCES}

1 Thomas DP. Sailors, scurvy and science. J R Soc Med 1997;90:50-4. Comments: J R Soc Med 1997;90:238,299,415,526-7

2 Hemilä H. Do vitamins $C$ and E affect respiratory infections? [Dissertation]. Helsinki, Finland: University of Helsinki, 2006:1-9,58-67,101-4. Available at http://ethesis.helsinki.fi/julkaisut/laa/kansa/vk/hemila/

3 Hess AF. Scurvy: Past and Present. Philadelphia, PA: Lippincott, 1920:88, 99. Available at http://chla.library.cornell.edu/

4 Hemilä H, Louhiala P. Vitamin C for preventing and treating pneumonia. Cochrane Database Syst Rev 2007; issue 1: CD005532.pub2

5 Mizgerd JP. Lung infection-a public health priority. PLoS Med 2006;3: e76.

6 Hughes RE. Nonscorbutic effects of vitamin C: biochemical aspects. Proc R Soc Med 1977;70:86-9

7 Levine M, Rumsey SC, Daruwala R, Park JB, Wang Y. Criteria and recommendations for vitamin C intake. JAMA 1999;281:1415-23

8 Glazebrook AJ, Thomson S. The administration of vitamin $\mathrm{C}$ in a large institution and its effect on general health and resistance to infection.J Hyg (London) 1942;42:1-19

9 Kimbarowski JA, Mokrow NJ. Colored precipitation reaction of the urine according to Kimbarowski as an index of the effect of ascorbic acid during treatment of viral influenza [In German]. Deutsche Gesundheitswesen 1967;22:2413-8. Translation available at http:// www.ltdk.helsinki.fi/users/hemila/T4.pdf

10 Pitt HA, Costrini AM. Vitamin C prophylaxis in marine recruits. JAMA 1979;241:908-11 
11 Mochalkin NI. Ascorbic acid in the complex therapy of acute pneumonia [In Russian]. Voenno-Meditsinskii Zhurnal 1970;9:17-21. Translation available at http://www.ltdk.helsinki.fi/users/hemila/ T5.pdf

12 Hunt C, Chakravorty NK, Annan G, Habibzadeh N, Schorah CJ. The clinical effects of vitamin $\mathrm{C}$ supplementation in elderly hospitalised patients with acute respiratory infections. Int J Vitamin Nutr Res 1994; 64:212-9

13 Merchant AT, Curhan G, Bendich A, Singh VN, Willett WC, Fawzi WW. Vitamin intake is not associated with community-acquired pneumonia in US men. J Nutr 2004;134:439-44

14 Hemilä $\mathrm{H}$. Vitamin $\mathrm{C}$ intake and susceptibility to the common cold. $\mathrm{Br}$ J Nutr 1997;77:59-72. Comments: Br J Nutr 1997;78:857-66

15 Hemilä H, Kaprio J, Albanes D, Virtamo J. Physical activity and the risk of pneumonia in male smokers administered vitamin $\mathrm{E}$ and $\beta$ carotene. Int J Sports Med 2006;27:336-41

16 Douglas RM, Hemilä H. Vitamin C for preventing and treating the common cold. PLoS Med 2005;2:e168

17 Ashton T, Young IS, Peters JR, et al. Electron spin resonance spectroscopy, exercise, and oxidative stress: an ascorbic acid intervention study. J Appl Physiol 1999;87:2032-6

18 Food and Nutrition Board, Institute of Medicine. Dietary Reference Intakes for Vitamin C, Vitamin E, Selenium and Carotenoids. Washington DC: National Academy Press, 2000:155-61. Available at http:// www.nap.edu/books $/ 0309069351 / \mathrm{html} / 155 . \mathrm{html}$

19 Cathcart RF. Vitamin C, titrating to bowel tolerance, anascorbemia, and acute induced scurvy. Med Hypotheses 1981;7:1359-76

20 Padayatty SJ, Sun H, Wang Y, et al. Vitamin C pharmacokinetics: implications for oral and intravenous use. Ann Intern Med 2004;140: $533-7$

$21 \mathrm{WHO} / \mathrm{NHD} / 99.11$. Scurvy and its Prevention and Control in Major Emergencies. Geneva: World Health Organization, 1999:1-12. Available at http://whqlibdoc.who.int/hq/1999/WHO_NHD_99.11.pdf
22 Fain $\mathrm{O}$, Mathieu E, Thomas M. Scurvy in patients with cancer. BMJ 1998;316:1661-2

23 Hampl JS, Taylor CA, Johnston CS. Vitamin C deficiency and depletion in the United States: the Third National Health and Nutrition Examination Survey, 1988 to 1994. Am J Public Health 2004;94:870-5. Correction in: Am J Public Health 2004;94:1078

24 Chiplonkar SA, Agte VV, Mengale SS, Tarwadi KV. Are lifestyle factors good predictors of retinol and vitamin C deficiency in apparently healthy adults? Eur J Clin Nutr 2002;56:96-104. Correction in: Eur J Clin Nutr 2003;57:628

25 Bates CJ, Prentice A, Cole TJ, et al. Micronutrients: highlights and research challenges from the 1994-5 National Diet and Nutrition Survey of people aged 65 years and over. Br J Nutr 1999;82:7-15

26 Villalpando S, Montalvo-Velarde I, Zambrano N, et al. Vitamins A, and $\mathrm{C}$ and folate status in Mexican children under 12 years and women 12-49 years: a probabilistic national survey. Salud Pública de México 2003;45(Suppl 4):S508-19

27 Matilainen T, Vartiainen E, Puska P, et al. Plasma ascorbic acid concentrations in the Republic of Karelia, Russia and in North Karelia, Finland. Eur J Clin Nutr 1996;50:115-20

28 Rao S, Yajnik CS, Kanade A, et al. Intake of micronutrient-rich foods in rural Indian mothers is associated with the size of their babies at birth: Pune Maternal Nutrition Study. J Nutr 2001;131:1217-24

29 Bates CJ, Prentice AM, Prentice A, Paul AA, Whitehead RG. Seasonal variations in ascorbic acid status and breast milk ascorbic acid levels in rural Gambian women in relation to dietary intake. Trans $R$ Soc Trop Med Hyg 1982;76:341-7

30 Hodges RE, Hood J, Canham JE, Sauberlich HE, Baker EM. Clinical manifestations of ascorbic acid deficiency in man. Am J Clin Nutr 1971; 24:432-43 